\title{
A KÖRNYEZETVÉDELEMMEL KAPCSOLATOS HOZZÁÁLLÁS KÖZÉPISKOLÁS DIÁKOK KÜLÖNBÖZŐ SZEGMENSEI MENTÉN
}

\author{
Kiss Virág Ágnes
}

\begin{abstract}
Absztrakt: A fenntartható fejlődés érdekében a közös cél a fogyasztói társadalmat egy tudatosabb életvitellel megismertetni és szokásrendszerükbe implementálni annak normáit. Jelen kutatásban egy napi rutinjaiban és fogyasztói magatartásában még kiforratlan csoportot, a középiskolás korosztályt vizsgáltuk egy 1002 fös kérdöíves felmérés keretében. Korábbi kutatások során már elkülönítettünk négy klasztert a tudatos fogyasztás ismérvei mentén. Ezen a négy klaszteren vizsgáltuk meg statisztikai elemzések segítségével, hogy hogyan differenciálódnak az egyes azonos korosztályhoz tartozó csoportok a környezettudatosság és a környezetvédelem kapcsán. Az eredményeink alapján kiderült, hogy eltéröek a gondolkodás- és a viselkedésminták a különböző szintű tudatosságot mutató klaszterekben, így a tudatos életvitel kialakításához szükséges a célcsoportoknak megfelelö kommunikáció, (elsősorban ismeretátadás), illetve a cselekvési lehetöségek biztosítása.
\end{abstract}

Abstract: The common aim of sustainable development is to get the consumer society to know a more conscious lifestyle and to implement its norms into their habitual systems. In our current research we examine a group which is yet immature in the field of its daily routine and consumer behaviour, namely the secondary school students. We did it in the way of a questionnaire survey included 1002 members. During previous researches we have already separated four clusters along the criteria of conscious consuming. Then we statistically examined how the age groups differentiate in environmental consciousness and protection within these clusters. The results showed that the thinking- and behavioural patterns are quite different in clusters with various consciousness, therefore giving proper communication (primarily knowledge transmission) and providing opportunities for act are essential for creating a conscious way of life.

Kulcsszavak: környezettudatosság, fiatalok, fenntarthatóság

Keywords: environment-conscious, young, sustainability

\section{Bevezetés}

A középiskolás korosztály attitüdjei nagyon fontosak a gazdaság és a társadalom minden szereplőjének, hiszen ők a jövő munkavállalói, a következő fogyasztói generáció, sőt a legtöbben már ebben a korban is aktív fogyasztóknak minősülnek, leginkább az élelmiszeripar ágazatai számára. A külső környezeti tényezőknek akárcsak más szocializációs folyamatra - az ebben a korban kialakuló fogyasztói magatartásukra komoly befolyásuk van.

A fenntartható fejlödés fogalmának elterjedése elött már megszületett az a gondolat, hogy a gazdasági növekedés és a fogyasztás olyan formája lenne hosszútávon fenntartható, amely a természeti erőforrásokat és azok megújulását nem veszélyezteti, ezáltal az emberi életet is támogatja, mely a természeti környezet nélkül nem tud életben maradni.

A környezet állapotával és annak az emberi életre való hatásával kapcsolatos aggodalmak a 20. század közepén fogalmazódtak meg, de fokozott környezetterhelés kialakulását a szakirodalomban az ipari forradalom kezdetére datálják (Nagy, 2011; Majláth, 2009). 
A fenntartható fejlödés a mai napig leggyakrabban idézett és elfogadott meghatározása is ebben kerül megfogalmazásra: „A fenntartható fejlödés olyan fejlödés, amely kielégíti a jelen szükségleteit, anélkül, hogy veszélyeztetné a jövö nemzedékek esélyét arra, hogy ök is kielégithessék szükségleteiket”. Ezt a kezdeti lendületet több tudományos kutatás és a környezetvédelemmel kapcsolatos szemléletváltás követte, majd újabb nemzetközi konferenciák, jelentések (Láng, 2001; Szlávik, 2002; Valkó, 2003; Csete, 2012). A környezetünk korábban tapasztalt minőségi romlása nem csupán bizonyos régiókat érint, hanem globális szinten jelenik meg, és a megoldásra komplex és több dimenziót parallel figyelembe vevő szemléletre van szükség, mely csak hosszú távon kivitelezhető (Láng, 2001).

A fenntartható fejlődés fogalmának tudományos és közéleti alkalmazása kapcsán érdemes kiemelni, hogy a brundtland-i jelentésében megjelenő népszerü megfogalmazás elég tág értelmezést enged meg. Ebböl is fakadhat, hogy számos eltérö gondolatmenet párosul hozzá, vagy hivatkozik rá (Dombi, 2013; Blewitt, 2015). A fogalom kapcsán több szerzőt számba véve azt látjuk, hogy az emberi életminőség veszélyeztetése vagy épp annak javítása áll a középpontban, amelyet a gazdaság, illetve a megfelelő intézményi háttér befolyásol olyan formában, hogy a jelen és jövőbeni társadalom igényeit és elvárásait a környezet károsítása nélkül tudja kielégíteni (Allen, 1980; Allaby, 1988; Markandya-Pearce, 1988; Liverman et al., 1988; Constanza-Wainger, 1991; O'Riordan-Vaeger, 1994 idézi SSI, 2015).

A környezettudatosság fogalma öt komponens alapján foglalható össze: ökológiai tudás, környezeti értékek, illetve attitüdök, cselekvési hajlandóság, továbbá tényleges cselekvés (Nemcsicsné, 2005; Marjainé et al., 2012), illetve magába a magatartásformába beletartozik az aktív környezetbarát és környezetvédő politizálás és a kapcsolódó szerveződések (Hofmeister et al., 2011). Meffert és Kirchgeorg (1994) kiemelték e tekintetben a következö a környezettudatos cselekvési típusokat:

- A hagyományos feldolgozású termékek fogyasztásának csökkentése, illetve róluk való lemondás;

- Keresletmódosítás - környezetbarát termékek vásárlása a hagyományos helyett;

- Környezetbarát termékek fogyasztása;

- Részvétel az újrahasznosításban, szelektív hulladékgyüjtésben;

- Környezettudatos panasz, tiltakozás (Nagy, 2011).

Célcsoportunkat figyelembe véve találkozhatunk kutatásokkal velük kapcsolatban is. Egy 10-18 évesek és felnőttek körében végzett vizsgálatában a fenntarthatósággal kapcsolatban olyan kapcsolatot talált, hogy míg a felnötteknél az attitüd erösebben hat a környezettudatos cselekvésre, mint a tudás, addig a fiatalok esetében a kettő ugyanakkora arányban jelenik meg motiváló erőként (Michalos et al., 2009; Marjainé et al., 2012). Egy vizsgálatban azt találták, hogy az idő elörehaladtával a fiatalok egyre több forrásból tájékozódnak a környezetvédelemmel kapcsolatban. Ezek közül is a legnépszerübbek a TV, a rádió és tanárok voltak (Asunta, 2004; Marjainé et al., 2012). A kutatók is felismerték, hogy a mai fiatalok környezettudatossággal kapcsolatos tájékoztatásában az internet fontos mediátor 
lehet, mely számukra - mint digitális bennszülöttek (Prensky, 2001) - az egyik legjobban ismert, és legtöbbet használt eszköz az információszerzéshez (Marjainé et al., 2012).

A környezettudatos életforma vagy környezetvédelem már nem csak morális kérdés. Komoly piaci vonzerővel rendelkezik. A Tudatos Vásárlók Egyesülete, a Magnet Bank és GfK együttmúködésével létrehozott Tudatos Vásárlói Piaci Jelentésben arról számolnak be, hogy a hazai háztartások közül is egyre nagyobb arányban választják a környezettudatos, etikus vagy a biotermékeket. 2014 és 2016 között 359 milliárd feletti összeget költöttek olyan élelmiszerekre, melyek a környezet, a közösség vagy a saját egészégüket támogatták. Ezek közül is kiemelkedik a piacok és a biopiacok forgalma, mely 334 milliárd volt. Az élelmiszereken túl nőtt a közösségi közlekedés, a biciklizés és a környezetbarát technológiák támogatottsága is (TVE, 2017).

\section{Anyag és módszer}

A vizsgálatot 2015-ben és 2016-ban végeztük kérdőíves felmérés keretében. A kutatásban 13 intézmény 1300 diákja vett részt. A kérdőívek feldolgozása után 1002 fő került a mintába. A minta kor és nem szerint reprezentatív erre a korosztályra. A korábbi vizsgálatok során már elvégeztünk egy faktor és klaszterelemzést, melyek segítségével négy klasztert különítettünk el (1. ábra). A négy csoport elnevezése a faktorokkal végzett ANOVA vizsgálatok és a demográfiai háttér változókkal végzett kereszttáblás elemzés után történt (Kiss et al., 2016).

\section{1. ábra: A tudatos életstílus klaszterek az egyes faktorok mentén}

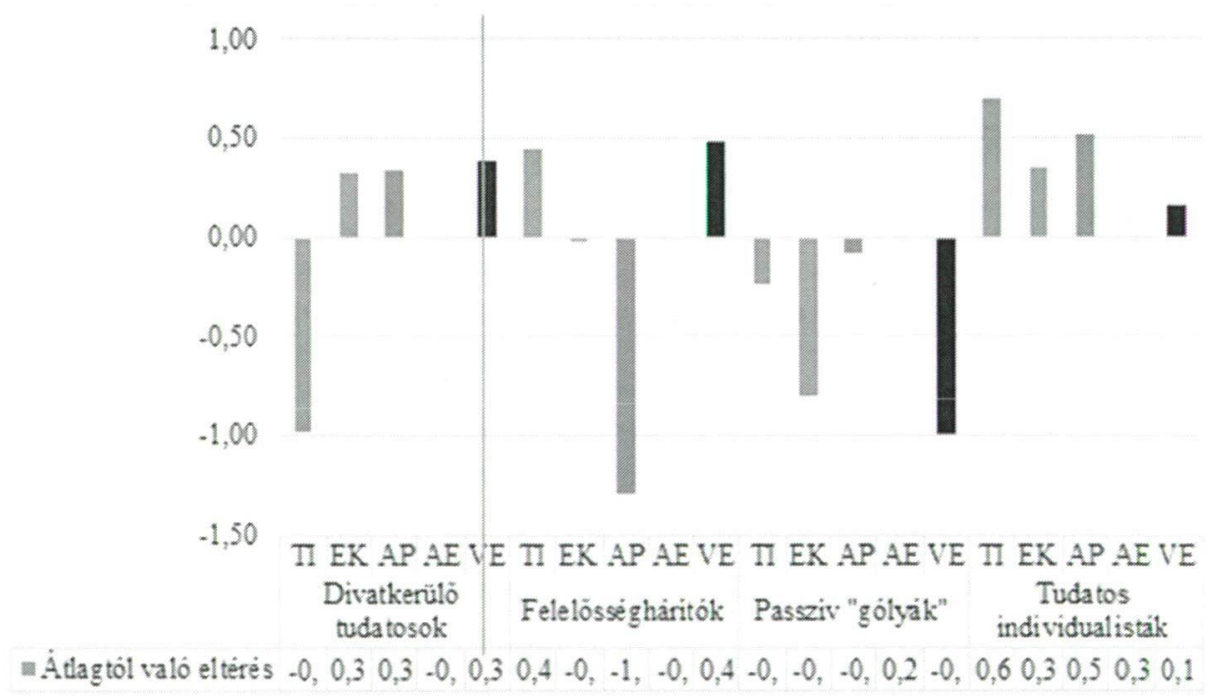

Forrás: Kiss et al., 2016. Megjegyzés: TI - trendkövető individuális, EK - egészség- és környezettudatos, $\mathrm{AP}$ - autentikus patrióta, $\mathrm{AE}$ - altruista etikus, $\mathrm{VE}$ - vállalati etikusság elvárása 
A faktor- és klaszterelemzés után 879 fö maradt a mintában. A faktorok kialakítása az egyes állítások mentén történt. A trendkövető individuális faktorban a divat, a minőség és az ezekhez kapcsolódó önkifejezés szerepeltek. Az egészség- és környezettudatossághoz kapcsolódó állítások, melyek az egészég és a környezet fontosságán túl az ezekhez kapcsolódó aktív cselekvésről szóltak, itt egy faktorba rendeződtek. Az autentikus patrióta elnevezést a faktor a hazai termékek preferálása és a hagyományok tisztelete miatt kapta. Az altruista etikus értékcsoportban az önkéntesség, az etikus magatartás elemei kerültek. A vállalati etikusság esetében pedig olyan állítások kerültek egy csoportba, melyek a vállalatokkal szemben támasztott elvárások mentén tömörültek egybe, mint a jótékonyság vagy a megfelelö, etikus munkakörülmények biztosítása (Kiss et al., 2016).

A faktorok kombinációi - a klaszterelemzés után - az egyes klasztereket jól megkülönböztetik egymástól. Az egyes csoportok a Divatkerülő tudatosok (225fö), a Felelősséghárítók (158fö), a Passzív alsóévesek, „gólyák” (209fö) és a Tudatos Individualisták (287 fö) voltak. Külön kiemelésre méltó, hogy az utolsó csoport esetében a divatkövetés és a tudatos fogyasztás egyaránt megjelenik, és demográfiai hátterük alapján ők azok, akik mind kulturális, mind anyagi tőke tekintetében fontos jelentőséggel bírnak (Kiss et al., 2016). Ezen kívül a felnőtteket érintő korábbi felmérések esetében ilyen pozitív értékekkel nem találkoztak a kutatók (Rácz, 2013; Szakály et al., 2015). Ez a csoport azért különleges, mert a megfelelő ïzenetekkel ők egy trendeket követő, megfelelő anyagi háttér rendelkező tudatos csoport lehetnek felnőttkorukban is, akik nyitottak újdonságokra és érdeklődnek az egyéni és a közösségi szintü tudatosság iránt is.

Az egyes csoportok esetében külön kíváncsiak voltunk a természeti környezettel kapcsolatos attitüdjeikre az teljes minta és a többi csoport átlagaihoz képest. Ezen vizsgálathoz varianciaanalízist végeztünk hét környezettudatossághoz kapcsolódó állítás bevonásával. A szignifikancia szint minden állítás esetében megfelelő volt $(\mathrm{p}<0,001)$.

\section{Eredmények}

Bár a faktorok esetében már megjelent a környezettudatosság mint érték és a hozzákapcsolódó cselekvési lehetőségek, mint energiatakarékosság és újrahasznosított csomagolóanyagok preferálása, de kíváncsiságunk tárgyát képezte, hogy vajon mekkora különbség mutatkozik a környezetvédelem fontosságának megítélése vagy az ahhoz kapcsolódó tudásuk kapcsán. A kérdőívben elhelyezésre keruilt egy negatív kérdés is, mely az általános válaszadási megfontoltságot volt hivatott ellenőrizni, illetve egyfajta ellenpólusként jelent meg az állítások között.

A vizsgálat után az egyes klaszterek mentén láthatjuk, hogy nagy különbségek mutatkoznak a környezet fontosságának megítélése, a tájékozottság, illetve a környezettel kapcsolatos állításokkal való egyetértés esetében (1. táblázat). 


\section{1. táblázat: A környezettel kapcsolatos állítások megítélése az egyes klaszterek mentén}

\begin{tabular}{|l|c|c|c|c|c|}
\cline { 2 - 6 } \multicolumn{1}{c|}{} & $\begin{array}{c}\text { Teljes } \\
\text { minta }\end{array}$ & $\begin{array}{c}\text { Divatkerülö } \\
\text { tudatosak }\end{array}$ & $\begin{array}{c}\text { Felelösség- } \\
\text { hárítók }\end{array}$ & $\begin{array}{c}\text { Passzív } \\
\text { gólyák }\end{array}$ & $\begin{array}{c}\text { Tudatos } \\
\text { individualisták }\end{array}$ \\
\hline $\begin{array}{l}\text { Szükséges, hogy a gyerekek } \\
\text { környezettudatos nevelésben } \\
\text { részesüljenek. }\end{array}$ & 4,29 & 4,54 & 4,18 & 3,68 & $\mathbf{4 , 6 0}$ \\
\hline $\begin{array}{l}\text { Jobban oda kellene figyelni a } \\
\text { környezetünkre. }\end{array}$ & 4,20 & $\mathbf{4 , 5 0}$ & 4,06 & 3,64 & 4,43 \\
\hline $\begin{array}{l}\text { A környezetvédelemmel } \\
\text { kapcsolatban tájékozott vagyok. }\end{array}$ & 3,97 & 4,07 & 3,94 & 3,57 & $\mathbf{4 , 2 1}$ \\
\hline $\begin{array}{l}\text { Fontos a környezet védelem } \\
\text { nekem. }\end{array}$ & 3,93 & 4,16 & 3,72 & 3,46 & $\mathbf{4 , 1 8}$ \\
\hline $\begin{array}{l}\text { Az emberiség túlélésének kulcsa, } \\
\text { hogy az ember harmóniában } \\
\text { éljen a természettel. }\end{array}$ & 3,81 & 4,10 & 3,63 & 3,21 & $\mathbf{4 , 1 2}$ \\
\hline $\begin{array}{l}\text { A természet egyensúlya kényes } \\
\text { és könnyen felborulhat. }\end{array}$ & 3,59 & 3,77 & 3,47 & 3,08 & $\mathbf{3 , 8 7}$ \\
\hline $\begin{array}{l}\text { Az embernek nem kell a } \\
\text { kömyezethez alkalmazkodnia, } \\
\text { mert irányítani tudja azt. }\end{array}$ & 2,24 & 1,97 & 2,10 & $\mathbf{2 , 6 2}$ & 2,26 \\
\hline
\end{tabular}

Forrás: Saját szerkesztés, 2017; N= 879 Módszer: One-way ANOVA; Sig: p<0,001; félkövér: legmagasabb átlag

A teljes minta átlagai alapján helyeztük csökkenő sorrendbe az egyes állatásokat. Általánosságban elmondható. hogy az egyes állításokkal való egyetértés, amelyekben a természet és ember kölcsönhatása került kiemelésre, kevésbé fontosak számukra, mint az általánosan elismert gondolatmenet, hogy a környezet védelme és ismerete fontos. A leginkább támogatott gondolat, hogy a környezettudatos nevelés szükséges a gyerekek számára. Ami viszont árnyalja a képet, hogy a Tudatos Individualisták 0,9-del ítélik fontosabbnak ennek oktatásba emelését, mint a Passzív alsóéves „gólyák”, akik minden állítás esetében a legrosszabb átlagokat hozták. Náluk egyedül az ellenőrzőkérdésként is funkcionáló állítás átlaga magasabb a többiekénél $(2,62)$. Náluk a környezeti kérdések nem szerepelnek a mindennapos életük főbb problémái között. Ez abból is fakad, hogy ők azok, akik a legrosszabb anyagi körülmények közül érkeztek, illetve a legalacsonyabban edukált szülőkkel rendelkeznek. Ebben az esetben viszont a maslow-i szükségletpiramisból kiindulva a fiziológiai és biztonsági szint kielégítése nélkül nem is elvárható, hogy magasabb rendủ célokra törekedjenek.

A legjobb eredményeket a Tudatos individualisták csoportja érte el majd' minden állítás esetében. Ök maguk tájékozottságukat megfelelőnek érzik, elkötelezettségükben biztosabbak, mint társaik, és az egyes természet és ember kölcsönhatását érintő állításokkal is jobban egyetértenek. Ök a divat által is megnyerhetőek, mozgósíthatók, ha fogyasztói mozgalomról van szó. Elköteleződésüket, mely most még külső és belső motivációra egyaránt épül, érdemes megerösíteni, fenntartani. 
A másik tudatosság szempontjából elkötelezett csoport a Divatkerülő tudatosok, akik alig lemaradva a Tudatos Individualistáktól szintén mind a természetes környezetre való odafigyelést, mind az általános cselekvést ezzel kapcsolatban támogatják. Sőt a negatív állítás esetén náluk volt a legalacsonyabb az átlag, azaz ők értettek egyet legkevésbé azzal, hogy az ember képes lehet teljes mértékben uralni és irányítani a környezetét. Náluk viszont nem jelenik meg a trendkövetés, sőt erősen elutasítják a trendkövetés mozgalmát. Náluk valószínüleg meglévő környezettudatos attitüd a szociális hátterükre és saját meggyőződésükre épül, ami hosszabb távon tartható fenn, mint a divatkövetők esetében. Anyagi helyzetük is rosszabb annál, hogy csak divatból ne legyenek árérzékenyek, nekik erösebb hatás kell.

A Felelősséghárítók esetében láthatjuk, hogy ők, akik a saját felelősséget elutasítják a tudatos életvitel kapcsán (Kiss et al., 2016), jellemzően ők állnak a legközelebb a teljes minta átlagához. Egyet is értenek, de nem annyira érzik sem a fontosságot, sem az elköteleződést, mint a másik két tudatosabb csoport. Rájuk demográfiai szempontból sem jellemző semmilyen különleges ismérv (Kiss et al., 2016). Öket valószínüleg csak egy-egy divathullám kedvéért lehetne kimozdítani a passzív, hárító magatartásból a tudatosság irányába.

\section{4. Összefoglalás}

A tanulmány egy rövid betekintést kívánt adni arról, hogy a középiskolás korosztályra sem tekinthetünk homogén csoportként. Akár az állami, vagy azon belül is az oktatásügyi szervezetek, akár a piaci, vállalati szereplők részéről tekintjük öket, érdemes szegmenseket, és azon belül is célcsoportokat létrehozni akár információátadásról, akár termékeladásról legyen szó.

Mindenképp pozitív tendenciaként beszélhetünk arról, hogy a felmérésünk alapján az elkötelezödés a környezettudatosság irányában pozitív a diákság körében. Természetes nem az aktív cselekvést mutatják az eredmények, de pozitív trendként tekinthetünk az érdeklödésre és a figyelemre, mely a mintában szereplő diákok több mint felét érinti.

Ez alapján a javaslat, hogy a megfelelö üzenetek segítségével igyekezzen mindenki elérni a számára kiemelt fontossággal bíró középiskolás csoportokat, és ne tekintsen rájuk se homogén tömegként, mert a differenciálatlan marketing - legyen szó iskolai rendezvényről, oktatófüzetről vagy környezettudatos termékekről hatástalanná vagy épphogy ellenállást kiváltó akcióvá válhat.

\section{Irodalomjegyzék}

Asunta, T. (2004): Knowledgesources, attitudes and self-reported behaviour of secondary-level science students concerning environmental topics. In: Laine, A. - Lavonen, J. - Meisalo, V. (eds.): Current research on mathematics and science education. University of Helsinki, Research Report, 253: 277-292.

Blewitt, J. (2015): Understanding sustainable development. Routledge, New York.

Csete (2012): Regionális és környezetgazdaságtan. Edutus Föikola, Budapest.

Dombi M. (2012): A környezeti hatások értékelésének lehetösége ökoszisztéma-szolgáltatások alapján. Tér és Társadalom, 26 (2): 40-56. 
Hofmeister Tóth Á., Kelemen K., Piskóti M. (2011): A fenntartható fogyasztás jellemzöi és trendjei Magyarországon és a régióban. In: Csutora M., Hofmeister Tóth Á. (Szerk.): Fenntartható fogyasztás? A fenntartható fogyasztás gazdasági kérdései AULA Kiadó, Budapest, 53-76.

Kiss V. Á., Kovács S., Szakály Z. (2016): A fenntartható fejlődés értékei és az egészségtudatos életstílus elemzése középiskolás diákok körében. Táplálkozásmarketing, 3 (2): 41-62.

Láng I. (2001): Stockholm - Rió - Johannesburg. Lesz-e új a nap alatt a környezetvédelemben? Magyar Tudomány, 2001/12. <http://www.matud.iif.hu/ 0ldec/lang.html> (2014. 12. 10.)

Majláth M. (2009): A pszichográfiai tényezők különbségei a környezetbarát és nem környezetbarát fogyasztók között. Doktori értekezés, Budapesti Corvinus Egyetem, Budapest.

Marjainé Szerényi Zs., Zsóka Á., Kocsis T., Széchy A. (2012): A fiatalok fogyasztási és életmódbeli szokásai a környezeti nevelés tiikrében. Mühelytanulmány. Budapesti Corvinus Egyetem, Környezetgazdaságtani és Technológiai Tanszék, Budapest.

Michalos, A. C., Creech, H., McDonald, C., Hatch Kahle, P. M. (2009): Measuring knowledge, attitudes and behaviours towards sustainable developement: Two exploratory studies. International Institute for Sustainable Development, Winniped.

Nagy Sz. (2011): Fenntartható fogyasztás. Nemzeti Tankönyv Kiadó, Budapest.

Nemcsicsné Zsóka Á. (2005): Következetesség és rések a környezettudatos szervezeti magatartásban, PhD Disszertáció, BCE, Budapest.

Prensky, M. (2001): Digital Natives, Digital Immigrants Part 1. On the Horizon, 9 (5): 1-6.

Rácz G. (2013): Az értékek változásának és a fenntartható fejlödés trendjének hatása a hazai élelmiszerfogyasztásra. Doktori értekezés, Szent István Egyetem, Gazdálkodás és Szervezéstudományok Doktori Iskola, Gödöllö.

Sustainable Society Index (2015): Notes and definition about Sustainability <http://www.ssfindex.com/sustainability/notes-and-definition> (2015.12.01.)

Szakály Z., Petö K., Popp J., Jasák H. (2015b): A LOHAS szegmens mérete és jellemzői Magyarországon. Táplálkozásmarketing, 2 (1): 10-30.

Szlávik J. (2002): A fenntarthatóság szintjei és útjai (A fenntartható fejlödés közgazdasági összefüggései). Akadémiai nagydoktori thesis. MTA, Budapest.

Tudatos Vásárlók Egyesülete (2017): Tudatos Vásárló Piaci Jelentés. <https://issuu.com/tudatosvasarlok/docs/tudatos_vasarlo_piaci_jelentes> (2017. 10. 22.)

Valkó L. (2003): Fenntartható/környezetbarát fogyasztás és a magyar lakosság környezeti tudata. BKAE Környezettudományi Intézetének tanulmányai, 18: 55. 